\title{
CHARACTERISTICS OF TEXTILE WASTE WATER OF BHILWARA (RAJASTHAN) AND ITS PHOTOCATALYTIC BLEACHING WITH $\mathrm{SnO}_{2}$ CATALYST
}

\author{
Kamod Singh Meena*, Kanta Meena** \\ * Manikya Lal Verma Government College, Department of Chemistry, Bhilwara, Rajasthan, India \\ ** Manikya Lal Verma Government College, Department of Botany, Bhilwara, Rajasthan, India \\ corresponding author: Kamod Singh Meena, e-mail: kamodsinghlectche@gmail.com
}

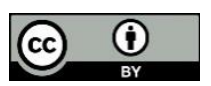

This work is licensed under a

Creative Commons Attribution 4.0

International License

Preliminary note

Received: April $3^{\text {rd }}, 2020$

Accepted: May $6^{\text {th }}, 2020$

HAE -1948

https://doi.org/10.33765/thate.11.1.2

\begin{abstract}
During the last decade, Bhilwara has developed into a leading place in the textile industry in India. The water used in textile industry is almost entirely discharged as waste. The effluents are very complex, containing salt, surfactants, ionic metals and their metal complexes, toxic organic chemicals, biocides, and toxic anions, which are harmful to both flora and fauna existing on our planet. Degradation of these non-biodegradable organic compounds is not possible by conventional treatment processes. The analysis of waste water with different quality parameters and photocatalytic bleaching was examined by using UV light in photochemical reactor with $\mathrm{SnO}_{2}$ catalyst.
\end{abstract}

Keywords: Bhilwara, textile, waste water, $\mathrm{SnO}_{2}$

\section{INTRODUCTION}

Textile industries are among the most important industries in the world. Textile and dye-manufacturing industries discharge toxic and non-biodegradable dyes as waste water into the environment. In textile fibers processing, various chemicals are needed depending on the nature of the raw material and products. The main sources of pollution in textile waste water are dyeing and finishing processes. These processes require wide range of chemicals and dyes; these chemical and dyes have high content of complex-structure organic compounds. Since not all of them are converted in the final product, waste disposal problems are created in environment $[1,2]$.

Textile waste waters are characterised with highly suspended solids, high chemical oxygen demand, dark colour, acidity, heat and other soluble substances. The residual colour of waste water is due to insoluble dyes. The dyes are of low biodegradability, so that textile dyes come into water and cause water pollution. Waste waters are huge environmental challenge for textile industry, not only as liquid waste, but also due to its chemical composition. If these effluents are improperly treated, they create serious threats to all 
species on the Earth and in the environment [3 - 5].

Production processes not only generate heavily polluted waste water, but also waste heat, solid waste and exhaust gas. Generally, textile mills produce mixed waste water in large quantities, up to $600 \mathrm{~m}^{3}$ per $\mathrm{kg}$ fabric, those are characterized by high organic load, having chemical oxygen demand (COD) of up to 1000 $\mathrm{mg}$ due to the presence of dyes [6]. Large quantities of water are consumed for the washing of the fabric. After washing, process industries produce huge amount of waste water. In order to comprehend the effluent problems facing the textile industry it is necessary to be familiar with the processes, which result with effluent production. Advanced oxidation processes (AOPs) are the most widely used approach employed for dye degradation $[7,8]$.

\section{Study area}

The geographical area of the Bhilwara district is 1047451 ha large and situated in the Rajasthan state. The Banas River is the only main seasonal river in the district. The district has made an important place for itself in the industrial map of the state. Bhilwara is known as "Textile City" due to the hub of textile industries in the state of Rajasthan.

\section{EXPERIMENTAL}

Five waste water samples of major textile industrial area of Bhilwara were collected from different locations in clean polyethylene bottles. The following parameters of samples were analysed: $\mathrm{pH}$, EC (electrical conductivity), turbidity, TSS (total suspended solids), TDS (total dissolved solid), BOD (biological oxygen demand) and COD (chemical oxygen demand) to determine characteristics of waste water $[9,10]$.

Photo catalytic treatments of effluents were performed by photochemical reactor in $254 \mathrm{~nm}$
UV radiation [11, 12]. The spectra were taken with UV-VIS spectrometer, $\mathrm{pH}$ meter was used to adjust the $\mathrm{pH}$ of the solution [13].

Photocatalyst: The $\mathrm{SnO}_{2}$ catalyst was a GR (guaranteed reagent) grade Meark material of $99 \%$ purity and was used without any further treatment $[14,15]$.

Process: Bleaching of textile waste with $\mathrm{SnO}_{2}$ reagent was performed by taking $50 \mathrm{ml}$ stock solution of textile waste water in a beaker and adding distilled water to make up $100 \mathrm{ml}$ sample solution. This sample solution was exposed to UV light in a photo chemical reactor. The progress of photo bleaching of textile waste water was analysed by determining its absorbance after every half an hour by spectrophotometer $[16,17]$.

\section{RESULTS AND DISCUSSION}

\section{Characteristics of waste water}

The waste water quality status from textile industries area is presented in Figures 1 - 7 .

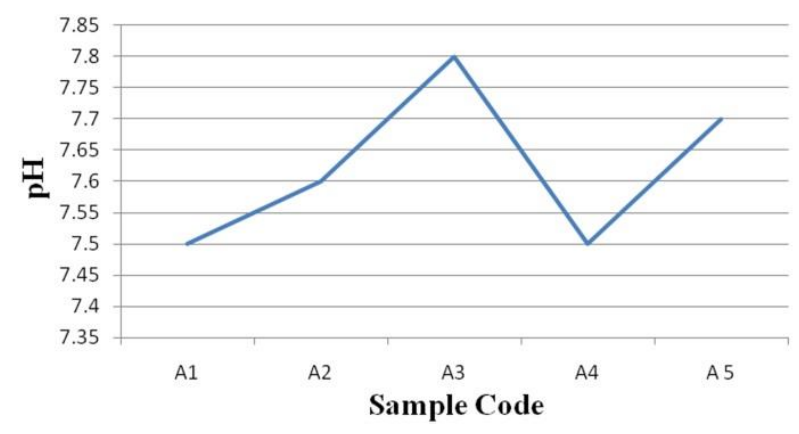

Figure 1. pH of samples

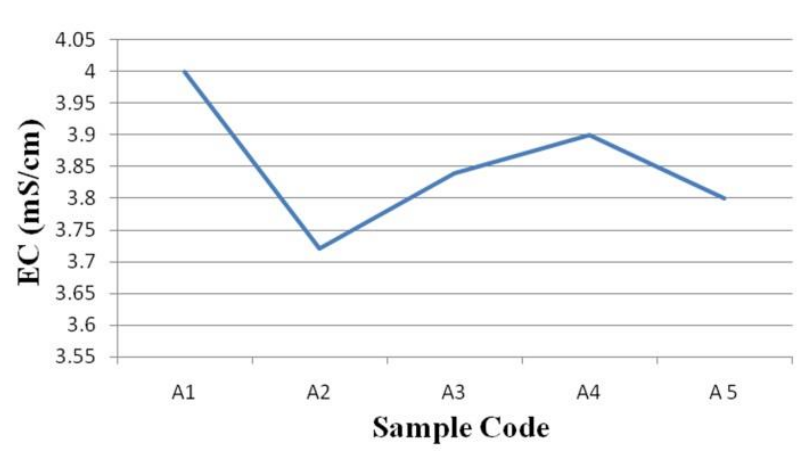

Figure 2. EC of samples 


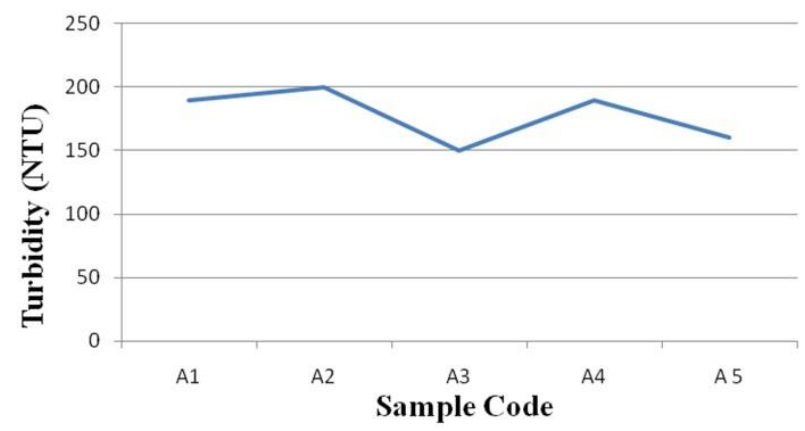

Figure 3. Turbidity of samples

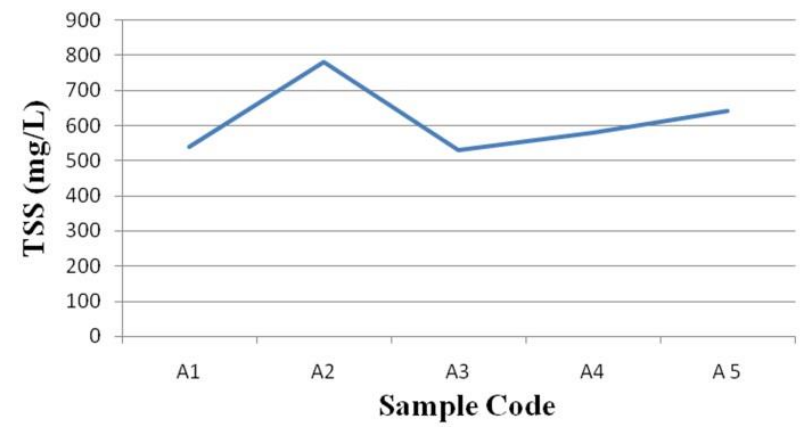

Figure 4. TSS in samples

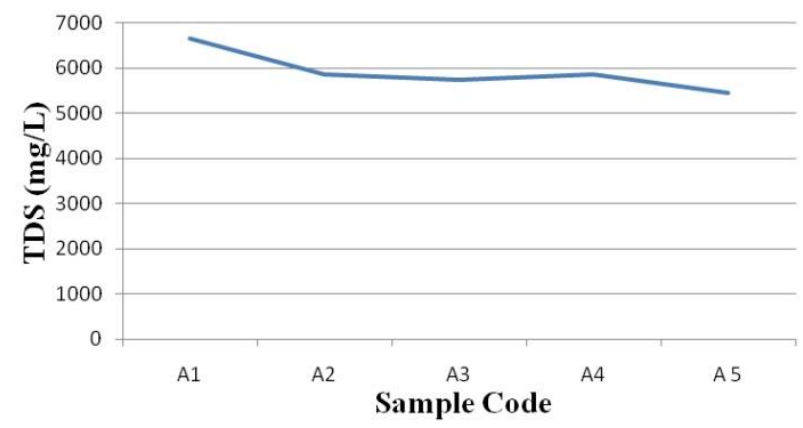

Figure 5. TDS in samples

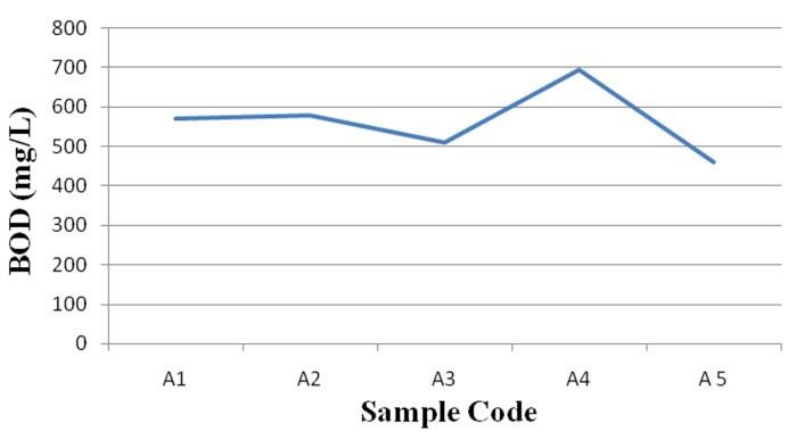

Figure 6. BOD of samples

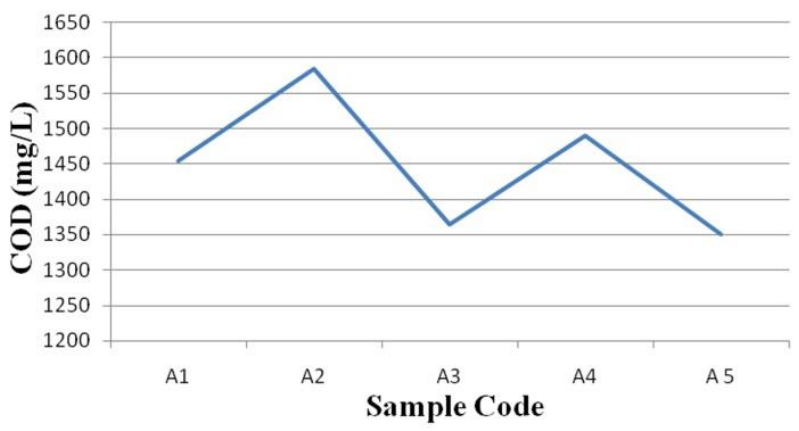

Figure 7. COD of samples

The lowest $\mathrm{pH}$ value was observed in A1 (7.5 $\mathrm{pH})$ station and the highest value was reported from A3 station ( $\mathrm{pH} 7.8$ ) (Figure 1). Electrical Conductivity ranged from 3.72 to $4.00 \mathrm{mS} / \mathrm{cm}$ (Figure 2). Turbidity varied from 160 to 200 NTU (Figure 3). The lowest value of turbidity was observed in A5 station and the highest value was observed in A2 station. The minimum TSS was determined in A1 station $(530 \mathrm{mg} / \mathrm{L})$ and the highest value was reported in A2 station $(780 \mathrm{mg} / \mathrm{L})$ (Figure 4). TDS ranged from 5460 to $6660 \mathrm{mg} / \mathrm{L}$ (Figure 5). The highest BOD value was found in A4 station $(695 \mathrm{mg} / \mathrm{L})$ and the lowest value was observed in A5 station (460 mg/L) (Figure 6). The COD ranged from $1350 \mathrm{mg} / \mathrm{L}$ to 1585 $\mathrm{mg} / \mathrm{L}$ (Figure 7).

According to National environmental quality standards (NEQS) for textile waste water, the desired $\mathrm{pH}$ is $6-10, \mathrm{EC}$ is $100 \mathrm{NTU}$, turbidity is $90 \mathrm{mg} / \mathrm{L}$, TSS value is $150 \mathrm{mg} / \mathrm{L}$, TDS value is $3500 \mathrm{mg} / \mathrm{L}, \mathrm{BOD}$ at $20{ }^{\circ} \mathrm{C}$ is $20 \mathrm{mg} / \mathrm{L}$, and $\mathrm{COD}$ value is $150 \mathrm{mg} / \mathrm{L}$. The parameters presented in Figures $1-7$ show that waste water is highly polluted. This waste water causes serious impacts on natural water bodies and soil in the surrounding area. High values of COD and BOD in the effluents causes depletion of dissolved oxygen, which has an adverse effect on the marine ecological system. High turbidity hampers the photosynthesis reaction, causing alteration in the habitat. Some diseases, like skin diseases, chemical burns, irritation, ulcers and even respiratory problems may appear. Therefore, waste water has to be treated before being discharged into the recipient surface water bodies within the specified disposable limits. 


\section{Photocatalytic bleaching}

As it is noticeable from the Figure 8, after adding $\mathrm{SnO}_{2}$ the waste water concentration in the solution decreased fast in initial hours, and then became slow and finally constant.

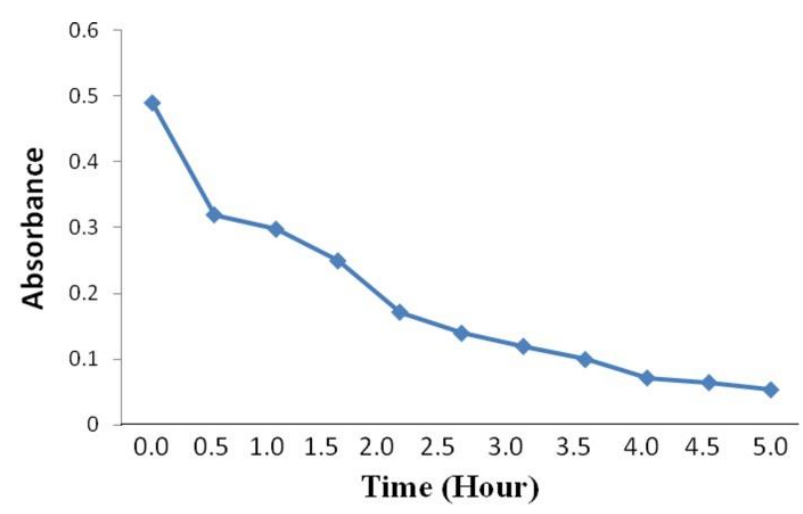

Figure 8. Bleaching of textile waste water by $\mathrm{SnO}_{2}$ reagent

About $60 \%$ waste water is degraded within the first hour, and in the next hour $67 \%$ degradation is completed. After 5 hours, about $89 \%$ degradation occurred. The waste water treatment target was $100 \%$ degradation, but after $5 \mathrm{~h}$ treatment almost no degradation of waste water compositions took place because textile waste water contains azo complex compounds.

\section{Influence of initial $\mathrm{pH}$}

The $\mathrm{pH}$ value plays an important role in the photo decolourization processes because $\mathrm{pH}$ affects the production of hydroxyl radical which is a powerful oxidizing agent. So, $\mathrm{pH}$ varied from 4.0 to 10 at $2.5 \mathrm{~g} / \mathrm{L}$ of catalyst dose during experimentation and it was found that with increasing $\mathrm{pH}$ there is a decrease in degradation rate.

\section{Variation of $\mathrm{SnO}_{2}$ catalyst dose}

In order to economize the process at the industrial scale, catalyst dose must be optimized. $\mathrm{SnO}_{2}$ catalyst was used in varying concentration from $1.25 \mathrm{~g} / \mathrm{L}$ to $5 \mathrm{~g} / \mathrm{L}$ at constant $\mathrm{pH} 4.0$ during the photocatalytic treatment for its optimization. The degradation efficiency was found to first increase up to a catalyst dose of $2.5 \mathrm{~g} / \mathrm{L}$ and then it decreased. It was also observed that efficiency of photo catalytic process increased with the rise in catalyst concentration up to a certain limit and then became constant and started to decrease after certain limit because waste water contained complex dyes, and surface area of dyes decreased.

\section{Effluent characteristics after photocatalytic treatment}

Photocatalytic treatment (Table 1) of waste water was performed in the UV reactor under optimized conditions, i.e. at $\mathrm{SnO}_{2}$ dose of 2.5 $\mathrm{g} / \mathrm{L}$ and operating $\mathrm{pH}$ of 4.5 . The results show that photocatalytic treatment did not affect the $\mathrm{pH}$ and the electrical conductivity, but turbidity shows an $86 \%$ reduction compared to the initial value. The results show the degradation of TSS by $76 \%$, TDS by $60 \%$, BOD by $35 \%$ and COD by $74 \%$. The degradation shows that textile waste water treatment by photocatalyst $\mathrm{SnO}_{2}$ is very effective.

Table 1. Characteristics of waste water after photocatalytic (UV) treatment under optimized condition

\begin{tabular}{|c|c|c|c|}
\hline S. No. & Parameter & Value & $\%$ Reduction \\
\hline 1. & $\mathrm{pH}$ & 7.03 & - \\
\hline 2. & $\begin{array}{c}\text { Electrical } \\
\text { conductivity } \\
\text { (mS/cm) }\end{array}$ & 4.03 & - \\
\hline 3. & Turbidity (NTU) & 20.20 & 86 \\
\hline 4. & $\begin{array}{c}\text { Total suspended } \\
\text { solids (mg/L) }\end{array}$ & 105 & 76 \\
\hline 5. & $\begin{array}{c}\text { Total dissolved } \\
\text { solid (mg/L) }\end{array}$ & 2370 & 60 \\
\hline 6. & $\begin{array}{c}\text { Biological oxygen } \\
\text { demand (mg/L) }\end{array}$ & 450 & 35 \\
\hline 7. & $\begin{array}{c}\text { Chemical oxygen } \\
\text { demand (mg/L) }\end{array}$ & 320 & 74 \\
\hline
\end{tabular}

\section{CONCLUSION}

The characterisation of the textile waste waters shows that these waters are highly polluted and are contaminated with dyes and other substance. All parameters are in high concentration; this waste contamination 
produces aquatic toxicity and it is harmful for mankind. If the discharge of these industries is assessed according to waste water quality criteria, additional treatment of this water is required before its discharge. The advanced treatment technologies might be used to treat the waste water from textile industries to such an extent of quality that could allow the waste water to be reused.

Photocatalytic degradation of wastewater has been investigated using $\mathrm{SnO}_{2}$ catalyst. It has been found that degradation is dependent upon various reaction parameters, such as amount of catalyst, dye concentration and $\mathrm{pH}$. The optimum conditions for degradation of applied wastewater are: $\mathrm{pH} 6.5,0.1 \mathrm{~g}$ of $\mathrm{SnO}_{2}, 100 \mathrm{ml}$ waste water. The photochemical bleaching of wastewater by $\mathrm{SnO}_{2}$ was effective in the disposal of waste water. The $\mathrm{SnO}_{2}$ photocatalysed decolouration of waste water is more effective and no other complex type was created and the recovering was done easily. In addition to the removal of colour, reaction also proceeds with the partial oxidation and it also completely degraded the toxic dye products. The existence of catalyst and lights are essential for photocatalytic bleaching of colouring dyes. Dye concentration and catalyst concentration have a considerable effect on bleaching efficiency. The scope of $\mathrm{SnO}_{2}$ photocatalyst is to synthesise nano-size so that decolouration is more effective for textile waste disposal and environment management.

\section{REFERENCES}

[1] K.S. Meena, A. Dadheech, Photocatalytic degradation of textile dyes Methylene blue and Reactive red 152 by $\mathrm{ZnO}$, Pollution Research 38(2019) 1, 221-225.

[2] N.A. Bhalerao, C.A. Moghe, R.S. Bhavsar, R.B. Kharat, Sludge management process - a review of its application to industrial sludges, Indian Journal of Environment Protection 7(1997), 535-541.
[3] S. Shanthi, R. Manjula, M. Vinulakshmi, R.R. Bala, Studies on the photodegradation of malachite green dye by the synthesized $\mathrm{ZnO}$ nano particles with different sources of energy, International Journal in Research Pharmacy and Chemistry 4(2014) 3, 571-576.

[4] R. Ameta, S.C. Ameta, Photocatalysis: Principles and Applications, CRC Press Published, Boca Raton, Florida, 2016.

[5] B. Gopal, Conservation of inland water in India, An overview, SIL Proceedings 25(1994), 2494-2506.

[6] T.W. Gebreslassie, M. Pattabi, R.M. Pattabi, Review on the Photocatalytic Degradation of Dyes and Antibacterial Activities of Pure and Doped-ZnO, International Journal of Science and Research 4(2015) 5, 2252-2264.

[7] R. Raliya, C. Avery, S. Chakrabarti, Photocatalytic degradation of methyl orange dye by pristine titanium dioxide, zinc oxide and grapheme oxide nanostructures and their composites under visible light irradiation, Applied Nanoscience 7(2017) 5, 253-259.

[8] A. Akbari, J.C. Remigy, P. Aptel, Treatment of textile dye effluent using a polyamide-based nanofiltration membrane, Chemical Engineering and Processing: Process Intensification 41(2002), 601-609.

[9] P. Grau, Textile industry wastewater treatment, Water Science \& Technology 24(1991) 1, 97-103.

[10] NEERI Feasibility report, Basic engineering package for Common Effluent Treatment Plant (CETP) at Pali, Rajasthan, 1993.

[11] APHA, AWWA, WEF, Standard methods for the examination of water and waste water, $20^{\text {th }}$ edition, Washington, USA, 1998.

[12] J.G. Calvert, J.N. Pitts, Photochemistry, Wiley \& Sons, New York, US, 1966.

[13] C. Xiaqing, W. Zhansheng, L. Dandan, G. Zhenzhen, Preparation of $\mathrm{ZnO}$ photocatalyst for the efficient and rapid photocatalytic degradation of azo dyes, 
Nanoscale research letters 12(2017), Article number: 143.

[14] K. Pamecha, V. Mehta, B.V. Kabra, Photocatalytic degradation of commercial textile azo dye Reactive Blue 160 by heterogeneous photocatalysis, Advances in Applied Science Research 7(2016) 3, 95-101.

[15] J.L. Wardell, Encyclopedia of Inorganic Chemistry, ed. R.B. King, John Wiley \& Son Ltd., 1995.

[16] P. Pichat, Photocatalysis and Water Purification: From Fundamentals to Recent Applications, Wiley Online Library, 2013.

[17] S. Sakthivel, B. Neppolian, M.V. Shankar, B. Arabindoo, M. Palanichamy, V. Murugesan, Solar photocatalytic degradation of azo dye: comparison of photocatalytic efficiency of $\mathrm{ZnO}$ and $\mathrm{TiO}_{2}$, Solar Energy Materials and Solar Cells 77(2003) 1, 65-82.

\section{Acknowledgements}

The authors are grateful to the Principal of Manikya Lal Verma Government College, Bhilwara and Head of Department of Chemistry, Manikya Lal Verma Government College, Bhilwara (Rajasthan) for providing necessary facilities. Authors are grateful to Dr. R.K. Gunsaria, associate professor, Department of Chemistry, University of Rajasthan, Jaipur for valuable suggestions. Financial assistance provided by the DST, Rajasthan, Jaipur to KSM under MRP is gratefully acknowledged. 